\title{
The Effect of Regular Exercise on Some Respiratory Parameters in Amateur Footballers and Wrestlers
}

\author{
Muhammed Fatih BİLİCí ${ }^{1}$, Ayça GENÇ ${ }^{2}$ \\ ${ }^{1}$ Muş Alparslan University, Muş, TURKEY \\ ${ }^{2}$ Bartın University, Bartın, TURKEY \\ Email: fatihbilic@hotmail.com
}

Type: Research Article (Received: 19.02.2020 - Corrected: ---- _ - Accepted: 24.03.2020)

\begin{abstract}
In this study, it was aimed to determine the effect of regular exercise on some respiratory parameters of amateur footballers and wrestlers. Respiratory parameters of the participants in the study were measured using a spirometer (PonyFx, Italy). SPSS program was used in the statistical analysis of the data obtained. The normality test was assessed by the Shapiro-wilk test. Descriptive statistics, one-way variance analysis (ANOVA) and Tukey HSD, one of the Post Hoc tests, were used to determine the direction of the group differences. Participants of the study were 60 voluntary men including 20 sedentary, 20 footballers and 20 wrestlers. Mean age, height and body weight of amateur wrestlers, footballers and sedentary respectively were $20.15,20.95$ and 20.20 years; $177.75,173.75$ and $173.20 \mathrm{~cm} ; 74.45,67.05$ and $67.70 \mathrm{~kg}$. Footbalers and wrestlers' FVC, FEV1, PEF (L / s), VC and MVV values were found to be statistically significantly higher than sedentary individuals $(\mathrm{p}<0.05)$. In addition, the FEV1 value of the wrestlers was significantly higher than the footballers $(p<0.05)$, while there was no statistically significant difference between the wrestlers and the footballers in other parameters $(\mathrm{p}>0.05)$. There was no statistically significant difference between the FEV1 / FVC (\%) and FEF25-75\% (L / s) values of the groups ( $>$ > 0.05). We think that regular exercise positively affects the respiratory functions, and when examined on the branch basis, there are differences in some parameters due to different training contents.
\end{abstract}

Keywords: Respiratory parameters, Wrestling, Football, Male 


\section{Introduction}

Exercise is a state of activity in which the cardiovascular system serves mainly. During exercise, the cardiovascular and respiratory mechanisms work in an organized manner, ensuring the adaptation of the body. The ability of the athlete to exercise in all branches depends on the amount of carrying oxygen to the tissues through the respiratory and circulatory system and capacity increase the carbon dioxide excretion from the body (Günay et al., 2018). Exercise improves the strength and endurance of the respiratory muscles and also contributes to the increase in lung volume and capacity and exercise increases physical capacity (Bilici and Güler, 2018; Leith and Bradley, 1976). Lung volume and capacity varies according to age, gender, body surface, status of being sedentary or athlete. With exercise, tidal and sediment volume, breathing capacity, functional sediment volume increase, breathing reserve volume and total lung capacity decrease, while exhalation reserve volume generally remains the same (Günay et al., 2013). In order to increase the physical performance of athletes, it is important to understand the working principle of the endocrine, muscular and respiratory system during exercise and plan appropriate physiological training accordingly. In resting without physical activity, respiratory volume of a person is 5-7 liters per minute and this may increase up to $140 \mathrm{lt}$ in a maximal exercise and $120 \mathrm{lt}$ in a submaximal exercise (McArdle et al., 1996). In a study that conducted, 20 weeks of regular exercise was found to increase the endurance of the respiratory muscles by $16 \%$ (White et al., 1991). When the literature is searched, it is emphasized that different sports branches have positive effects on lung capacities, and especially training and load intensity that increase vital capacity are very important. When the FVC values of different distance runners were analyzed, it was found that short distance runners had lower FVC values than medium and long distance athletes (Patlar et al., 2000; Schone et al., 1997). The development of respiratory muscle strength and functions is protective against pulmonary disorders, and it is supported by the literature that improving these functions positively affects the quality of life with regular exercise (Dübüş et al., 2011).

In this study, it was aimed to determine the effect of regular exercise on some respiratory parameters of amateur footballers and wrestlers.

\section{Method}

In the present study, without any health problems 60 participants included. These participants' features were 20 wrestlers with mean age 20.15 years, mean height $177.75 \mathrm{~cm}$, mean body weight $74.45 \mathrm{~kg}$, and, 20 footballers and 20 footballers with mean age 20.95 years, mean height $173.75 \mathrm{~cm}$, mean body weight $67.05 \mathrm{~kg}$, and lastly as a control group male sedentary volunteers with mean age 20.20 years, mean height $173.20 \mathrm{~cm}$, mean body weight $67.70 \mathrm{~kg}$. The inclusion criteria were determined in advance and candidates who did not comply with these criterias were excluded from the study. Inclusion criterias were; 1. for amateur footballers and wrestlers: to have at least four years of training age, not smoking and drinking alcohol; 2. for sedentary group: not to do any physical activity, bronchodilator drugs are not used.

\section{Spirometric Measurements}

Before the test, all participants were informed about the study, the behaviors and practices that may affect measurements. After voluntary informed consent forms and ethics committee approval from the Board of Scientific Research and Publication Ethics Committee of Mus 
Alparslan University dated 12/11/2019 and numbered 10879717-050.01.04, research had started.

Before the study, all participants were informed that they should not wear clothes that can tighten their rib cage, should not exercise heavily thirty minutes before the test, and should not consume fatty foods two hours before the test.

Respiratory function values of athletes and sedentary participants were measured using spirometry (PonyFx, Italy). All of the spirometric measurements were applied in sitting position. The tests were carried out after the participants' nose was closed with a latch, after they were used to breathe several times with the mouthpiece connected to the spirometry. The measurements were repeated 3 times and the best value was recorded.

\section{Statistical Evaluation}

SPSS package program was used for statistical analysis of the data. The normality of the data was carried out with the Shapiro-Wilk test. Descriptive statistics, one-way analysis of variance (ANOVA), and Tukey HSD, one of the Post Hoc tests, were used to determine the direction of intragroup difference.

\section{Results}

In this study we found body mass index $\left(\mathrm{kg} / \mathrm{m}^{2}\right)$ of participants as wrestlers 23.51 , footballers 22.24 and sedentary group 22.58 .

Table 1. Body weight, height, age and BMI values of wrestlers, footballers and sedentary group

\begin{tabular}{|l|l|l|l|l|}
\hline Groups & Body weight $(\mathbf{k g})$ & Height $(\mathbf{c m})$ & Age $($ year $)$ & $\begin{array}{l}\text { Body Mass Index } \\
\left(\mathbf{k g} / \mathbf{m}^{2}\right)\end{array}$ \\
\hline Wrestlers & 74.45 & 177.75 & 20.15 & 23.51 \\
\hline Footballers & 67.05 & 173.75 & 20.95 & 22.24 \\
\hline Sedentary & 67.70 & 173.20 & 21.20 & 22.58 \\
\hline
\end{tabular}

Table 2. Some respiratory function values of wrestlers, footballers and sedentary group

\begin{tabular}{|c|c|c|c|c|c|c|c|}
\hline Parameters & Groups & $\mathbf{N}$ & Mean & SD $( \pm)$ & $\mathbf{F}$ & $\mathbf{P}$ & $\begin{array}{l}\text { Direction } \\
\text { Differences }\end{array}$ \\
\hline \multirow{3}{*}{ FVC(L) } & Footballer & 20 & 5.27 & 0.57 & \multirow{3}{*}{11.65} & \multirow{3}{*}{$0.000 * *$} & \multirow{3}{*}{$\begin{array}{l}\text { Footballer-Sedentary } \\
\text { Wrestler-Sedentary }\end{array}$} \\
\hline & Wrestler & 20 & 5.60 & 0.51 & & & \\
\hline & Sedentary & 20 & 4.74 & 0.63 & & & \\
\hline \multirow{3}{*}{ FEV1(L) } & Footballer & 20 & 4.46 & 0.47 & \multirow{3}{*}{12.08} & \multirow{3}{*}{$0.000 * *$} & \multirow{3}{*}{$\begin{array}{l}\text { Footballer-Wrestler } \\
\text { Footballer-Sedentary } \\
\text { Wrestler-Sedentary }\end{array}$} \\
\hline & Wrestler & 20 & 4.86 & 0.46 & & & \\
\hline & Sedentary & 20 & 4.07 & 0.59 & & & \\
\hline \multirow{4}{*}{ FEV1/FVC(\%) } & Footballer & 20 & 84.84 & 6.17 & \multirow{3}{*}{0.75} & \multirow{3}{*}{0.477} & \multirow{3}{*}{$(\mathrm{p}>0.05)$} \\
\hline & Wrestler & 20 & 86.98 & 4.96 & & & \\
\hline & Sedentary & 20 & 85.83 & 5.40 & & & \\
\hline & Footballer & 20 & 8.36 & 1.38 & 9.07 & $0.000 * *$ & Footballer-Sedentary \\
\hline
\end{tabular}




\begin{tabular}{|c|c|c|c|c|c|c|c|}
\hline \multirow[t]{2}{*}{ PEF (L/s) } & Wrestler & 20 & 9.06 & 1.20 & & & \multirow[t]{2}{*}{ Wrestler-Sedentary } \\
\hline & Sedentary & 20 & 7.45 & 1.00 & & & \\
\hline \multirow{3}{*}{$\begin{array}{l}\text { FEF25-75\% } \\
(\mathrm{L} / \mathrm{s})\end{array}$} & Footballer & 20 & 4.93 & 0.91 & \multirow{3}{*}{0.67} & \multirow{3}{*}{0.517} & \multirow{3}{*}{$(p>0.05)$} \\
\hline & Wrestler & 20 & 5.57 & 0.97 & & & \\
\hline & Sedentary & 20 & 5.12 & 2.83 & & & \\
\hline \multirow{3}{*}{$\mathrm{VC}(\mathrm{L})$} & Footballer & 20 & 5.01 & 0.48 & \multirow{3}{*}{12.67} & \multirow{3}{*}{$0.000 * *$} & \multirow{3}{*}{$\begin{array}{l}\text { Footballer-Sedentary } \\
\text { Wrestler-Sedentary }\end{array}$} \\
\hline & Wrestler & 20 & 5.31 & 0.52 & & & \\
\hline & Sedentary & 20 & 4.35 & 0.81 & & & \\
\hline \multirow{3}{*}{ MVV (L/min) } & Footballer & 20 & 132.38 & 22.19 & \multirow{3}{*}{9.04} & \multirow{3}{*}{$0.000 * *$} & \multirow{3}{*}{$\begin{array}{l}\text { Footballer-Sedentary } \\
\text { Wrestler-Sedentary }\end{array}$} \\
\hline & Wrestler & 20 & 148.78 & 22.13 & & & \\
\hline & Sedentary & 20 & 120.48 & 18.91 & & & \\
\hline
\end{tabular}

$p<0,005$

Abbreviations: FVC(L) - Forced Vital Capasity; FEV1(L)- Forced Expiratory Volume in 1 second; FEV1/FVC (\%)-Forced; Expiratory Volume in 1 second )/Forced Vital Capasity; PEF (L/s)- Peak Expiratory Flow; FEF25-75\% (L/s)- Forced Expiratory Flow at 25-75\%; VC (L)- Vital Capacity; MVV (L/min)- Maximal Voluntary Ventilation

In Table 2, it is determined that the FVC, FEV1, PEF (L / s), VC and MVV values of footballers and wrestlers are statistically significantly higher than the sedentary ones $(p<0.05)$. Wrestlers FEV1 value was found to be significantly higher than footballers $(p<0.05)$, and there were no statistically significant differences between wrestlers and footballers in other parameters ( $p>0.05)$. There was no statistically significant difference between the FEV1 / FVC (\%) and FEF25-75\% (L / s) values of the groups ( $\mathrm{p}>0.05)$.

\section{Discussion}

The strong relation of exercise and lung cannot be ignored. MVV, FVC and FEV1 values decrease when there is a presence of the airways' narrowing in the lung, increased respiratory resistance or any obstruction. FEV1 and PEF (L / s) values give clues about the condition of large airways in the lung in general (Bilici andTürker, 2019). In the literature, it has been concluded in many of the previous studies that exercise affects the respiratory muscles and accordingly improves respiratory functions. (Gökdemir et al., 2007; Sable et al., 2012; Ahmadi et al., 2013;). In a study conducted to examine the respiratory functions of athletes, swimmers and sedentary ones, it was stated that the athletes (athletes and swimmers) have higher FVC and VC values than the sedentary ones (Doherty and Dimitriou, 2007). In the study that was examined, the respiratory functions of university students according to smoking and exercise variables, it was reported that individuals who do sports, have significantly higher FVC, FEV1, FEF25-75\% (L / s), VC and MVV values (Sedentary, 2019). In a study, the effect of exercise on different respiratory parameters in different branches were searched and, it was stated that athletes had higher VC, FVC, FEV1, MVV values compared to sedentary ones (Atan et al., 2013). In the study conducted on taekwondo athletes, it was stated that four week technical and tactical training increased the FVC, PEF and MVV values (Çakmakçı et al., 2009). In their research, Alpay et al. (2007) stated that basketball players with an average age of 12.6 years have significantly higher VC and FVC values compared to 
the same aged sedentary group (Alpay et al., 2007). In the study that was searched the effect of swimming exercise on FVC, FEV1 and MVV values in primary school children, it was stated that there was no significant difference between children doing sports and sedentary children (Çakır Atabek, 2017). As a result of our study, amateur footballers' and wrestlers' FVC, FEV1, PEF (L / s), VC and MVV values were stated to be statistically significantly higher than sedentary $(\mathrm{p}<0.05)$.

Looking at previous studies, although there are few studies that suggest that exercise improves respiratory functions similar to our study results, few studies suggest that exercise does not have a special effect on respiratory functions. We think that this difference may be caused by factors such as style and duration of the exercise, sport type, age, and gender.

In a study comparing the blood and respiratory functions of wrestlers and basketballers, it was reported that there was no statistically significant difference in FVC, FEV1, PEF (L / s), VC and FEV1 / FVC (\%) values between both branches (Kara et al., 2010). In a study that examined the respiratory functions in different sports branches, it is stated that the respiratory parameters vary according to the sports branch (Durmic et al., 2015). In another study related to swimmers, footballers and sedentary individuals, it is stated that swimmers' VC, FVC and FEV1 values are higher than footballers and sedentary ones. (Lazovic et al., 2016) In some previous studies, it has been stated that water sports improve respiratory functions more than land sports (Bloomfield et al., 1985; Cordain et al., 1990). In our study results, it was determined that the FEV1 (L) value of the wrestlers was statistically higher than the footballers $(p<0.05)$. In other parameters, there was no statistically significant difference between wrestlers and footballers $(p>0.05)$.

\section{Conclusion}

As a result, we think that regular exercise positively affects the respiratory functions, and leads differences in some respiratory parameters, in others, and the differences in these parameters result from different training methods that branch specified. 


\section{REFERENCES}

Ahmadi F, Zar A, Dalvand H, Salesi M (2013). Effect of Eight Week Endurance Training on Pulmonary Function in Sedentary Men. International Journal of Basic Sciences \& Applied Research, 2 (4): 405-411.

Alpay B, Altuğ K, Hazar, S (2007). Assessment of some respiratory and circulation parameters of 11-13 age group students in primary school teams by comparing them with untrained students. Mehmet Akif Ersoy University Journal of Education Faculty, 8: 22-29.

Atan T, Akyol P, Çebi M (2013). Bireysel sporlarla uğraşan yıldızlar kategorisindeki sporcuların solunum fonksiyonlarının karşılaştırılması. Dicle Medical Journal, 40 (2): 192198.

Bilici MF, Turker A (2019). Investigation of The Effects of Smoking Addiction and Physical Activity on Some Respiratory Functions in Young Adult Males. Journal of Education and Training Studies, 7(12):41-46.

Bilici MF, Güler MŞ (2018). The investigation of the acute effect of sparring training on some biochemical parameters in elite boxers.International journal of applied exercise physiology. 8(3.1):357-360.

Bloomfield J, Blansby BA, Ackland TR, Elliot BC (1985). The anatomi-cal and physiological characteristics of pre-pubertal adolescentswimmers, tennis players and non competitors. Aust Sci MedSport, 17:19-23.

Cordain L, Tucker A, Moon D, Stager J (1990). Lung volumes and max-imal respiratory pressures in collegiate swimmers and runners.Res Q Exerc Sport, 61:4-14.

Çakır Atabek H (2017). The effects of swimming training on selected strength and respiratory function variables in pre-pubertal children, Journal of Athletic Performance and Nutrition, 4 (1):17-33.

Çakmakçı E, Çınar V, Boyalı E (2009). Bayan Teakwondocularda kamp döneminin bazı solunum parametreleri üzerine etkisi. Atatürk Üniversitesi Beden Eğitimi ve Spor Bilimleri Dergisi,11:1-6.

Doherty M, Dimitriou L (2007). Comparison of lung volume in Grek swimmers, land based athletes and sedantery controls. Br J Sports Med,31:337 - 41.

Durmic T, Lazovic B, Djelic M, Lazic JS, Zikic D, Zugic V, Dekleva M, Mazic S (2015). Sport-specific influences on respiratory patterns in elite athletes. J Bras Pneumol, 41(6):516522.

Dübüş T, Toker A, Şükrü D, Kalaycı G (2011). Evaluation of quality of life longterm respiratory and functional capacity after lung cancer surgery. Turkish Journal of Thoracic and Cardiovascular Surgery, 19(2):227-233.

Günay M, Baltacı AK, Şıktar E, Şıktar E (2018). Egzersiz ve Solunum.Ankara:Gazi Kitabevi.

Günay M, Tamer K, Cicioğlu İ. (2013). Spor Fizyolojisi ve Performans Ölçümü. Ankara:Gazi Kitabevi.

Gökdemir K, Koç H, Yüksel O (2007). Aerobik antrenman programının üniversite öğrencilerinin bazı solunum ve dolasım parametreleri ile vücut yağ oranı üzerine etkisi, Egzersiz, 1:145-149. 
Kara E, Özal M, Yavuz HU (2010). Elit Güreşçi ve Basketbolcuların Kan ve Solunum Parametrelerinin Karşılaştırılması, Selçuk University Journal of Physical Education and Sport Science, 12 (1): 36-41.

Lazovic-Popovic B, Zlatkovic-Svenda M, Durmic T, Djelic M, Djordjevic Saranovic S, Zugic V (2016). Superior lung capacity in swimmers: Some questions, more answer! Rev Port Pneumol, 22(3):151-156.

Leith DE, Bradley M (1976).Ventilatory muscle strength and endurance training. J Appl Physiol, 41:508-516.

Mcardle WD, Katch FI, Katch VL (1996). Exercise physiology:energy,nutrition and human performance.Lea and Febiger, Philadelphia.

Sable M, Vaidya SM, Sable SS (2012). Comparative study of lung functions in swimmer and runners. Indian J Physiol Pharmacol, 56(1):100-104.

Schone RB, Giboney K, Schimmel C et al. (1997). Spirometry anda airway reactivity in elite track and field athletes. Clin J of Sport Med, 7:257-261.

Patlar S, Çumralıgil B, Kılıç M, Polat Y (2000). Futbolcularda sürekli koşular metodu ile oyun formu metodunun solunum parametreleri üzerine etkisi. S.Ü. Beden Eğit ve Spor Bil Dergisi, 2:62-69. 